\title{
On an Attempt to Study the Inter-relationships amongst Enablers of Inclusion of Neuro Diverse Individuals at Educational and Professional Workplaces
}

\author{
Ratna Banerjee \\ SOB, University of \\ Petroleum \& Energy \\ Studies, \\ Dehradun, India
}

\author{
Lakshay Aggarwal \\ Recventures Education \\ Services Private Limited, \\ Delhi, India
}

\author{
Remica Aggarwal \\ MIT-SOER, MIT- ADT \\ University, \\ Pune, India
}

\author{
V. K. Aggarwal \\ Recventures Education \\ Services Private Limited, \\ Delhi, India
}

\begin{abstract}
Diversity is an inherent part of the society. Neuro-diverse individuals are often characterized with challenges with social interaction, verbal and non-verbal communication and repetitive behaviors. They are gifted individuals who are brilliant at performing technology related tasks. However their talent and expertise need to be recognized and sharpen both at the societal, educational as well as at the workplace level so as to utilize their talent and expertise to its fullest. Present article focuses on therefore exploring various success factors behind the successful inclusion of neuro-diverse learners at classrooms as well as at workplaces . thereafter , it tries to study the inter-relationships amongst them using ISM methodology .
\end{abstract}

\section{Keywords}

Neurodiversity, ISM methodology ; Neuro-diverse individuals ; Autism ; Inclusive education ; Neuro-diverse classrooms

\section{INTRODUCTION}

About 15 years ago, activists for individuals with Autism coined the term neuro diversity as a way of helping to redefine their identity (Blume, 1998; Singer, 1999). However, this term has been extended to other neurodevelopmental conditions, such as dyslexia and attention deficit hyperactivity disorder (ADHD) as well. In varying degrees, these individuals can often be characterized by challenges with social interaction, verbal and nonverbal communications, emotional and behavioral disorders and repetitive behaviors (Hendrickx, 2010; Pollak, 2009, Armstrong, 2012). In extreme cases, cognitive impairments and sensory overload do occur. However, most autistic individuals are incredibly high performing and intellectually gifted . Their behavior may seem out of the ordinary, and yet they often excel in visual skills, music, math and art - sometimes surpassing their neurotypical peers.

Recognizing these gifts, and leveraging them by providing these students with respectful team roles that exploit these strengths, will build confidence and social connections.

At student / educational level : The population of students with acknowledged neurological differences has increased greatly in the past decade, and educators are seeing a greater neurodiversity in their classrooms every day. Students on the autism spectrum bring an incredible set of gifts into a makerspace. These students are gifted to take complex tasks be it complex mathematical programming or computer programming with ease.
At workplaces as well : Using novel methods for assessing, training, and managing neuro-diverse talent, companies such as SAP are demonstrating that the neuro-diverse approach to their workforce is yielding significant innovations by teams with employees on Autism as well as ADHD. The teams with neuro-diverse employees were instrumental in developing a technical change in one of their products, resulting in an estimated $\$ 40$ million in savings.

So how can we include them successfully at schools or educational institutions or at professional workplaces is the focal point of the present research. It aims at diagnosing and analyzing the various factors behind the successful inclusion of neuro diversity at educational level as well as at workplaces. Paper is organized as follows : Section 2 presents the literature review on the topic in concern of schools as well as workplaces. Section 3 presents the ISM methodology and section 4 presents the managerial implications.

\section{LITERATURE REVIEW}

\subsection{Success factors behind Inclusion of Neuro-Diverse Students at Inclusive Classrooms}

Students on Autism spectrum are not free from challenges . Be it possessing high anxiety levels or being affected by visual, auditory, and olfactory clutter as a benchmark of their neurodiversity. For students with autism, problem behaviors may include temper tantrums, running about the room, loud vocalizations, self-injurious activities, or other disruptive or distracting behaviors. As a teacher and mentor of these students, the key is how to react to their behaviors over time and how you use positive strategies to promote pro-social behaviors as possible.

Following are the success factors for integrate neurodiversity into educational practices:

\subsubsection{Positive View and Expectations (PVE):}

Neurodiversity emphasizes looking at students with special needs primarily in terms of their gifts and abilities, and uses these strengths to help them deal with their challenges. This positive view pays off in dividends as students rise to the expectations of their teachers.

2.1.2 Conversion of deficit paradigm to a Growth Paradigm (CDP) : People with neuro diversity possesses gifts that often dovetail with cutting edge careers in information technology, entrepreneurship, and science. It's time that special educators use this knowledge to help their students affirm positive futures for themselves. 
2.1.3 Inclusion education (CIE) : Students with special needs who are included in regular classrooms develop more positive views of themselves, form friendships with neurotypical kids, and are better able to keep up with the curriculum and learn important academic skills.

2.1.4 Neurodiversity alignment with school's other programs and policies on Diversity (ASP) : Virtually all schools have policies that promote the value of diversity, both cultural diversity (honoring students from different races, ethnic groups, gender roles, etc.) and bio-diversity (through classes and units on biology and related disciplines). Neurodiversity can be viewed as another positive contribution to diversity.

2.1.5 Reforming school curricula with Neurodiversity(RSC) : This means more hands-on learning, experiential learning, project-based learning, expeditionary learning, arts-based learning, brain-based learning, Universal Design for Learning, and other programs and projects that kids with neuro-diversities will have success with, and that will benefit every other student in school as well.

2.1.6 Reducing social, emotional and behavioral problems through Neurodiversity (RSEBP) : Bullying is one of the biggest problems in education today, resulting in untold social, emotional, and behavior problems that in many cases can last a lifetime for the bullied. Neurodiversity helps to change this situation by emphasizing (and promoting) the gifts and abilities of students with special needs, thus projecting a more powerful image to potential bullies, and thereby making them less of a target.

2.1.7 Extraordinary traits displayed by Neurodiverse Individuals (ET) : These individuals had both strengths and significant challenges. For example, Winston Churchill had a conduct disorder and a speech impediment. Henry Ford had learning disabilities. Thomas Edison had clear signs of ADHD. Agatha Christie had dyslexia. This should remind us that the kids with special needs in our classrooms may be the ones to make the crucial discoveries or the key decisions for our world in the coming decades.

2.1.8 Diversity of Minds (DoM) : Having variety of minds that can offer multitude of perspectives, views and solutions in the event of uncertainty could be a success factor .

2.1.9 Understanding concept of neuro diversity from the eyes of the beholder (UCND): In order to properly deal with students on the spectrum, you must have a working understanding of Autism. This helps a teacher to understand his students and their family more closely and developing stronger bonds and relationship with them at emotional level.

2.1.10 Establishing a working partnership with parents (EWP): Parents are your first and best source of information about their child. Building trust with the parents is essential. After that, establishing mutually agreed modes and patterns of communication with the family throughout the school year is critical.

2.1.11 Modifying the autistics of the classroom(MAC) or educational institution as per the needs of the child .

2.1.12 Educate Peers and Promote Social Goals (EP): You must make every effort to promote acceptance of the child with Autism as a full member and integral part of the class . As the teacher of a child with autism, you must create a social environment that encourages positive interactions between the child with autism and his or her typically developing peers.

\subsection{Success factors behind implementation of neuro diversity at workplaces 5,6}

The $21^{\text {st }}$-century companies should allow an environment where there is little noise and try not to have to have a workplace that has recognized a lot of verbal conflicts.

2.2.1 Training of co-workers (TOW) : Other "best practice" includes training of co-workers on the diverse challenges of Neuro-diverse individuals. This also includes training the neuro-diverse individuals regarding their responses to different situations and how can they improve upon them.

2.2.2 Sensitive training for supervisors and managers (STS): Management should learn how to adjust their interactions with neuro-diverse individuals. Neuro-diverse employees have reported bullying and discrimination against the companies they have worked with during their employment. The only way to eliminate this is by the training of supervisor/managers as well as employees.

2.2.3 On the job training for neuro diverse individuals (OJT): The Neuro-diverse employee should be given the time and the support on the job from fellow employees. Some neuro-diverse employees are better verbally, visually or in written directions. Some individuals lack eye contact, so supervisor and managers need to give the neuro-diverse employees direct feedback on how to do the job and why it is essential. For example, many Neuro-diverse employees do not understand sarcasm or regular sayings such as "provide customer service." On the job training also includes workplace etiquette and the unspoken rules in the workplace. The Neuro-diverse employee should also be encourages to ask questions in order to resolve their doubts .

2.2.4 Discussions to improve the performance (DIP): Neuro-diverse individuals have great intellect but need a structured employment environment. These individual have high rates of retention and low absenteeism (Pisano 2016). To improve the neuro-diverse individual's performance, be prepared to discuss work rules, provide structure work, prioritize work, organizing tasks daily, weekly and monthly.

2.2.5 Documentation of best practices and measurement of Neuro diversity program (DBP): Human Resources should document best practices and set the goals and measurement for the Neurodiversity program. What would success look like? Once that has been established, partnering with local disability offices and rehabilitation services to understand the programs that are afforded to Neuro-diverse employees could be encouraged.

2.2.6 Delivery of additional training (DAT) : Many of these organizations, neuro diverse employees with free training, job coaches, resume writing, interviewing skill training, etc.

2.2.7 Supportive and encouraging Interviewing (S\&EI) : Given the awkwardness and anxiety that some neuro-diverse talent experience when questioned, changing up the interview process presents a supportive environment and productive interactions. There is a need to create a situation that is better suited to autistic people's styles of communicating and thinking. Of course, the hiring manager remains the person who will extend or reject an offer.

2.2.8 Creation of a pilot program (CPP): A small pilot program could be design for the selected neurodiversity workers. Creating a sustainable environment where mentors 
understand that neuro-diverse talent may need more reassurance and clarity than their neurotypical colleagues. Allow workers to stumble, succeed and develop in a safe environment.

\section{INTERPRETIVE STRUCTURAL MODELLING METHODOLOGY}

Suggested by Warfield [], ISM works with the following steps: it starts with identifying the relevant elements and pairwise establishing the contextual relationship amongst them. Thereafter, a structural self-interaction matrix (SSIM) may be developed between two variables i.e. $i$ and $j$ establishing a "Lead to" relationship between criteria. Four symbols viz. V, $\mathrm{A}, \mathrm{X} \& \mathrm{O}$ are used for establishing the relationships. It further lead to developing initial reachability matrix and then a final reachability matrix after removing transitivity . Afterwards, the reachability set and antecedent set for each criterion and for each element can be obtained from the final reachability matrix . After that a level partition matrix can be obtained based on establishing the precedence relationships and arranging the elements in a topological order. Finally a Mic-Mac analysis is performed categorizing the variables in to autonomous, dependent, driver and linkage category.

\subsection{ISM model for the success factors behind inclusion of neuro-diverse} individuals in Educational setup

Fig 1: SSIM matrix for pair wise relationship amongst barriers
12 factors were identified viz. positive view and expectations (PVE); Conversion of deficit paradigm to a growth paradigm (CDP); Inclusion education (IE); Neurodiversity alignment with school's other programs and policies on diversity (ASP); reforming school curricula with neurodiversity (RSC); Reducing social, emotional and behavioral problems through Neurodiversity (RSEBP) ; Extraordinary traits displayed by Neuro-diverse Individuals (ET) ; Diversity of Minds (DoM) ; Understanding concept of neuro diversity from the eyes of the beholder (UCND) ; Establishing a working partnership with parents (EWP) ; Modifying the autistics of the classroom(MAC); Educate Peers and Promote Social Goals (EP).

\subsubsection{Construction of Structural Self -} Interaction Matrix (SSIM)

This matrix gives the pair-wise relationship between two variables i.e. I and $j$ based on VAXO. SSIM has been presented below in Fig 1 .

\subsubsection{Construction of Initial Reachability Matrix and final reachability matrix}

The SSIM has been converted in to a binary matrix called the initial reachability matrix shown in fig. 2 by substituting $\mathrm{V}, \mathrm{A}$, $\mathrm{X}, \mathrm{O}$ by 1 or 0 as per the case. After incorporating the transitivity, the final reachability matrix is shown below in the Fig 3.

\begin{tabular}{|c|c|c|c|c|c|c|c|c|c|c|c|c|c|}
\hline & Barriers & 1 & 2 & 3 & 4 & 5 & 6 & 7 & 8 & 9 & 10 & 11 & 12 \\
\hline & & PVE & CDP & IE & ASP & RSC & $\begin{array}{c}\text { RSE } \\
\text { BP }\end{array}$ & $\begin{array}{c}\text { ET } \\
\text { Mo } \\
\text { M }\end{array}$ & $\begin{array}{c}\text { UC } \\
\text { ND }\end{array}$ & $\begin{array}{c}\text { EW } \\
\text { P }\end{array}$ & MAC & EP \\
\hline 2 & CDP & & & X & X & A & V & X & A & X & A & A & A \\
\hline 3 & IE & & & & X & V & V & V & V & V & V & V & V \\
\hline 4 & ASP & & & & & X & V & V & X & V & V & V & V \\
\hline 5 & RSC & & & & & & V & V & V & V & V & V & V \\
\hline 6 & RSEBP & & & & & & & V & A & A & A & A & A \\
\hline 7 & ET & & & & & & & & A & A & A & A & A \\
\hline 8 & DoM & & & & & & & & & V & X & A & V \\
\hline 9 & UCND & & & & & & & & & V & V & V \\
\hline 10 & EWP & & & & & & & & & & & V & V \\
\hline 11 & MAC & & & & & & & & & & & & A \\
\hline 12 & EP & & & & & & & & & & & & \\
\hline
\end{tabular}

Fig 2: Initial reachability matrix

\begin{tabular}{|c|c|c|c|c|c|c|c|c|c|c|c|c|c|}
\hline & Barriers & 1 & 2 & 3 & 4 & 5 & 6 & 7 & 8 & 9 & 10 & 11 & 12 \\
\hline & & PVE & $\begin{array}{c}\text { CD } \\
\text { P }\end{array}$ & IE & ASP & RSC & $\begin{array}{c}\text { RSE } \\
\text { BP }\end{array}$ & ET & $\begin{array}{c}\text { D } \\
\text { o } \\
\text { M }\end{array}$ & $\begin{array}{c}\text { UC } \\
\text { ND }\end{array}$ & $\begin{array}{c}\text { EW } \\
\text { P }\end{array}$ & MAC & EP \\
\hline 1 & PVE & 1 & 1 & 1 & 1 & 1 & 1 & 1 & 1 & 1 & 1 & 1 & 1 \\
\hline 2 & CDP & 0 & 1 & 1 & 1 & 0 & 1 & 1 & 0 & 1 & 0 & 0 & 0 \\
\hline 3 & IE & 0 & 1 & 1 & 1 & 1 & 1 & 1 & 1 & 1 & 1 & 1 & 1 \\
\hline 4 & ASP & 0 & 1 & 1 & 1 & 1 & 1 & 1 & 1 & 1 & 1 & 1 & 1 \\
\hline 5 & RSC & 0 & 1 & 0 & 1 & 1 & 1 & 1 & 1 & 1 & 1 & 1 & 1 \\
\hline 6 & RSEBP & 0 & 0 & 0 & 0 & 0 & 1 & 1 & 0 & 0 & 0 & 0 & 0 \\
\hline
\end{tabular}




\begin{tabular}{|c|c|c|c|c|c|c|c|c|c|c|c|c|c|}
\hline 7 & ET & 0 & 1 & 0 & 0 & 0 & 0 & 1 & 0 & 0 & 0 & 0 & 0 \\
\hline 8 & DoM & 0 & 1 & 0 & 1 & 0 & 1 & 1 & 1 & 1 & 1 & 0 & 1 \\
\hline 9 & UCND & 0 & 1 & 0 & 0 & 0 & 1 & 1 & 0 & 1 & 1 & 1 & 1 \\
\hline 10 & EWP & 0 & 1 & 0 & 0 & 0 & 1 & 1 & 1 & 0 & 1 & 1 & 1 \\
\hline 11 & MAC & 0 & 1 & 0 & 0 & 0 & 1 & 1 & 1 & 0 & 0 & 1 & 0 \\
\hline 12 & EP & 0 & 1 & 0 & 0 & 0 & 1 & 1 & 0 & 0 & 0 & 1 & 1 \\
\hline
\end{tabular}

Fig 3 : Final reachability matrix

\begin{tabular}{|c|c|c|c|c|c|c|c|c|c|c|c|c|c|c|}
\hline & Barriers & 1 & 2 & 3 & 4 & 5 & 6 & 7 & 8 & 9 & 10 & 11 & 12 & \\
\hline & & PVE & CDP & IE & ASP & RSC & $\begin{array}{c}\text { RSEB } \\
\text { P }\end{array}$ & $\begin{array}{c}\text { ET } \\
\text { Do } \\
\text { M }\end{array}$ & $\begin{array}{c}\text { UCN } \\
\text { D }\end{array}$ & $\begin{array}{c}\text { EW } \\
\text { P }\end{array}$ & $\begin{array}{c}\text { MA } \\
\text { C }\end{array}$ & EP & D.P \\
\hline 1 & PVE & 1 & 1 & 1 & 1 & 1 & 1 & 1 & 1 & 1 & 1 & 1 & 1 & 12 \\
\hline 2 & CDP & 0 & 1 & 1 & 1 & 1 & 1 & 1 & 1 & 1 & 1 & 1 & 1 & 11 \\
\hline 3 & IE & 0 & 1 & 1 & 1 & 1 & 1 & 1 & 1 & 1 & 1 & 1 & 1 & 11 \\
\hline 4 & ASP & 0 & 1 & 1 & 1 & 1 & 1 & 1 & 1 & 1 & 1 & 1 & 1 & 11 \\
\hline 5 & RSC & 0 & 1 & 1 & 1 & 1 & 1 & 1 & 1 & 1 & 1 & 1 & 1 & 11 \\
\hline 6 & RSEBP & 0 & 1 & 0 & 0 & 0 & 1 & 1 & 0 & 0 & 0 & 0 & 0 & 3 \\
\hline 7 & ET & 0 & 1 & 1 & 1 & 0 & 1 & 1 & 0 & 1 & 0 & 0 & 0 & 6 \\
\hline 8 & DoM & 0 & 1 & 1 & 1 & 1 & 1 & 1 & 1 & 1 & 1 & 1 & 1 & 11 \\
\hline 9 & UCND & 0 & 1 & 1 & 1 & 0 & 1 & 1 & 1 & 1 & 1 & 1 & 1 & 8 \\
\hline 10 & EWP & 0 & 1 & 1 & 1 & 0 & 1 & 1 & 1 & 1 & 1 & 1 & 1 & 10 \\
\hline 11 & MAC & 0 & 1 & 1 & 1 & 0 & 1 & 1 & 1 & 1 & 1 & 1 & 0 & 9 \\
\hline 12 & EP & 0 & 1 & 1 & 1 & 0 & 1 & 1 & 1 & 1 & 0 & 1 & 1 & 9 \\
\hline & De.P & 1 & 12 & 11 & 11 & 6 & 12 & 12 & 10 & 11 & 9 & 10 & 9 & \\
\hline
\end{tabular}

D.P : Driving power ; De.P : dependence power

\subsubsection{Level Partition}

From the final reachability matrix, reachability and final antecedent set for each factor are found. The elements for which the reachability and intersection sets are same are the top-level element in the ISM hierarchy. After the identification of top level element, it is separated out from the other elements and the process continues for next level of elements. Reachability set, antecedent set, intersection set along with different level for elements have been shown below in table 4.1.3.1 to table 4.1.3.6.

Table 4.1.3.1: Iteration I

\begin{tabular}{|c|c|c|c|c|}
\hline S.No. & Reachability set & Antecedent set & Intersection set & Level \\
\hline 1. & $2,6,7$ & $\begin{array}{c}1,2,3,4,5,6,7,8,9 \\
10,11,12\end{array}$ & $2,6,7$ & \multirow{7}{*}{$\mathbf{I}$} \\
\hline 2. & $2,3,4,6,7,9$ & $1,2,3,4,5,7,8,9,10,11,12$ & $2,3,4,7,9$ & \\
\hline 3. & $2,3,4,6,7,8,9,11$ & $\begin{array}{c}1,2,3,4,5,8,9,10 \\
11,12\end{array}$ & $2,3,4,8,9,11$ & \\
\hline 4. & $\begin{array}{c}2,3,4,6,7,8,9,11, \\
12\end{array}$ & $\begin{array}{c}1,2,3,4,5,8,9,10, \\
12\end{array}$ & $2,3,4,8,9,12$ & \\
\hline 5. & $\begin{array}{c}2,3,4,6,7,8,9,10, \\
11,12\end{array}$ & $1,2,3,4,5,8,9,10$ & $2,3,4,8,9,10$ & \\
\hline 6. & $2,3,4,5,6,7,8,9,10,11,12$ & $1,2,3,4,5,8,9$ & $2,3,4,5,8,9$ & \\
\hline 7. & $\begin{array}{c}1,2,3,4,5,6,7,8,9 \\
10,11,12\end{array}$ & 1 & 1 & \\
\hline
\end{tabular}


Table 4.1.3.2: Iteration II

\begin{tabular}{|c|c|c|c|c|}
\hline S.No & Reachability set & Antecedent set & $\begin{array}{c}\text { Intersection } \\
\text { set }\end{array}$ & Level \\
\hline 2. & $3,4,9$ & $\begin{array}{c}1,3,4,5,8,9,10 \\
11,12\end{array}$ & $3,4,9$ & \multirow{6}{*}{ II } \\
\hline 3. & $3,4,8,9,11$ & $\begin{array}{c}1,3,4,5,8,9,10 \\
11,12\end{array}$ & $3,4,8,9,11$ & \\
\hline 4. & $3,4,8,9,11,12$ & $1,3,4,5,8,9,10,12$ & $3,4,8,9,12$ & \\
\hline 5. & $\begin{array}{c}3,4,8,9,10,11 \\
12\end{array}$ & $1,3,4,5,8,9,10$ & $3,4,8,9,10$ & \\
\hline 6. & $3,4,5,8,9,10,11,12$ & $1,3,4,5,8,9$ & $3,4,5,8,9$ & \\
\hline 7. & $\begin{array}{c}1,3,4,5,8,9,10 \\
11,12\end{array}$ & 1 & 1 & \\
\hline
\end{tabular}

Table 4.1.3.3 : Iteration III

\begin{tabular}{|c|c|c|c|c|}
\hline $\begin{array}{c}\text { S.No } \\
\cdot\end{array}$ & Reachability set & $\begin{array}{c}\text { Antecedent } \\
\text { set }\end{array}$ & $\begin{array}{c}\text { Intersection } \\
\text { set }\end{array}$ & Level \\
\hline 3. & $\mathbf{8 , 1 1}$ & $1,5,8,10,11,12$ & 8,11 & \\
\cline { 1 - 4 }. & $8,11,12$ & $1,5,8,10,12$ & 8,12 & \multirow{2}{*}{ III } \\
\cline { 1 - 4 } 5. & $8,10,11,12$ & $1,5,8,10$ & 8,10 & \\
\cline { 1 - 4 } 6. & $5,8,10,11,12$ & $1,5,8$ & 5,8 & \\
\hline 7. & $1,5,8,10,11,12$ & 1 & 1 & \\
\hline
\end{tabular}

Table 4.1.3.4 : Iteration IV

\begin{tabular}{|c|c|c|c|c|}
\hline $\begin{array}{c}\text { S. } \\
\text { No. }\end{array}$ & $\begin{array}{c}\text { Reachability } \\
\text { set }\end{array}$ & $\begin{array}{c}\text { Antecedent } \\
\text { set }\end{array}$ & $\begin{array}{c}\text { Intersection } \\
\text { set }\end{array}$ & Level \\
\cline { 1 - 4 } & $\mathbf{1 2}$ & $1,5,10,12$ & 12 & \multirow{2}{*}{ IV } \\
\cline { 1 - 3 } 5. & 10,12 & $1,5,10$ & 10 & \\
\cline { 1 - 3 } 6. & $5,10,12$ & 1,5 & 5 & \\
\hline 7. & $1,5,10,12$ & 1 & 1 & \\
\hline
\end{tabular}

Table 4.1.3.5: Iteration V

\begin{tabular}{|c|c|c|c|c|}
\hline $\begin{array}{c}\text { S. } \\
\text { No. }\end{array}$ & $\begin{array}{c}\text { Reachability } \\
\text { set }\end{array}$ & $\begin{array}{c}\text { Antecedent } \\
\text { set }\end{array}$ & $\begin{array}{c}\text { Intersection } \\
\text { set }\end{array}$ & Level \\
\hline 6 & $\mathbf{1}$ & 1 & $\mathbf{1}$ & V \\
\hline 7 & $\mathbf{7}$ & 7 & 7 & \\
\hline
\end{tabular}

\subsubsection{Classification of factors}

The critical success factors described earlier are classified in to four clusters viz. autonomous factor, dependent factors, linkage factors and independent / Driving factors are mentioned below.

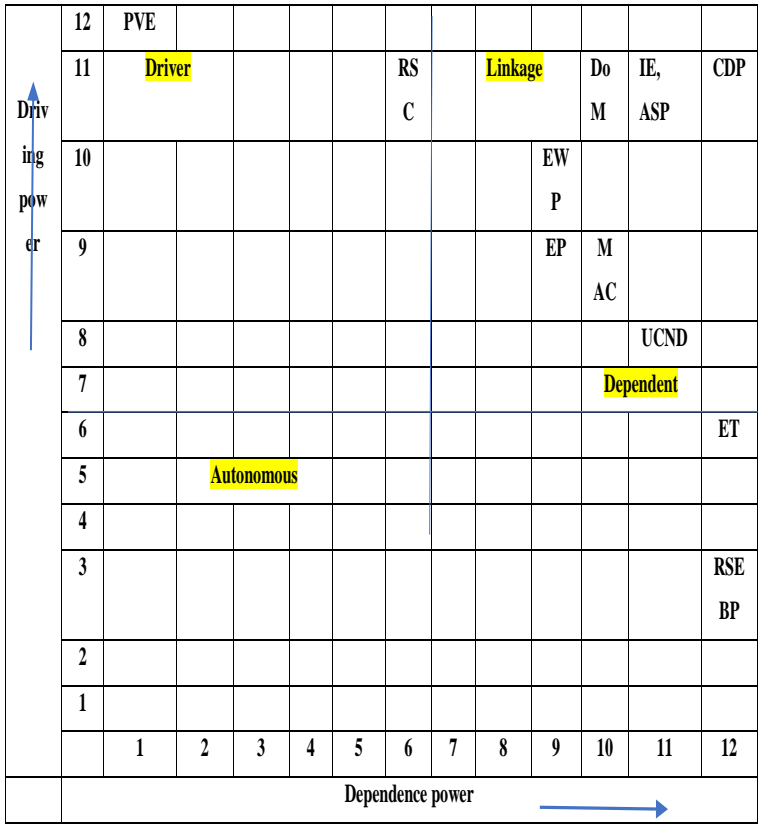

\subsection{ISM Methodology for case example of Indian Denim wear for Men}

Similarly, around 8 challenges have been recognized in denim wear industry viz. Youth as a growth driver (YGD) ; Influence of international brand (IIB) ; Increased rural spending (IRS); Inclination towards western trends (IWT) ; Casualization of fashion (COF) ; Alternative retail channel (ARC); Rise of private label (RPL); Best performing categories of denim wear (BPC). These are studied further for the possible interrelationships amongst them using ISM methodology .

\subsubsection{Construction of Structural Self - Interaction Matrix (SSIM) :}

This matrix gives the pair-wise relationship between two variables i.e. $i$ and $j$ based on VAXO. SSIM has been presented below in table 4.2.1.1.

Table 4.2.1.1: Structural Self- Interaction Matrix

\begin{tabular}{|c|c|c|c|c|c|c|c|c|c|}
\hline & $\begin{array}{c}\text { Barri } \\
\text { ers }\end{array}$ & 1 & 2 & 3 & 4 & 5 & 6 & 7 & 8 \\
\hline & & $\begin{array}{c}\text { YG } \\
\text { D }\end{array}$ & $\begin{array}{c}\text { II } \\
\text { B }\end{array}$ & $\begin{array}{c}\text { IR } \\
\text { S }\end{array}$ & $\begin{array}{c}\text { IW } \\
\text { T }\end{array}$ & $\begin{array}{c}\text { CO } \\
\text { F }\end{array}$ & $\begin{array}{c}\text { AR } \\
\text { C }\end{array}$ & $\begin{array}{c}\text { RP } \\
\text { L }\end{array}$ & $\begin{array}{c}\text { BP } \\
\text { C }\end{array}$ \\
\hline 1 & YGD & & V & V & V & V & V & V & V \\
\hline 2 & IIB & & & V & A & V & A & A & A \\
\hline 3 & IRS & & & & A & A & A & A & A \\
\hline 4 & IWT & & & & & V & V & V & V \\
\hline 5 & COF & & & & & & A & A & A \\
\hline 6 & ARC & & & & & & & A & A \\
\hline 7 & RPL & & & & & & & & A \\
\hline 8 & PC & & & & & & & & \\
\hline
\end{tabular}


Table 4.2.1.2: Initial reachability matrix

\begin{tabular}{|c|c|c|c|c|c|c|c|c|c|}
\hline & $\begin{array}{c}\text { Barri } \\
\text { ers }\end{array}$ & 1 & 2 & 3 & 4 & 5 & 6 & 7 & 8 \\
\hline & & $\begin{array}{c}\text { YG } \\
\text { D }\end{array}$ & $\begin{array}{c}\text { II } \\
\text { B }\end{array}$ & $\begin{array}{c}\text { IR } \\
\text { S }\end{array}$ & $\begin{array}{c}\text { IW } \\
\text { T }\end{array}$ & $\begin{array}{c}\text { CO } \\
\text { F }\end{array}$ & $\begin{array}{c}\text { AR } \\
\text { C }\end{array}$ & $\begin{array}{c}\text { RP } \\
\text { L }\end{array}$ & $\begin{array}{c}\text { BP } \\
\text { C }\end{array}$ \\
\hline 1 & YGD & 1 & 1 & 1 & 1 & 1 & 1 & 1 & 1 \\
\hline 2 & IIB & 0 & 1 & 1 & 0 & 1 & 0 & 0 & 0 \\
\hline 3 & IRS & 0 & 0 & 1 & 0 & 0 & 0 & 0 & 0 \\
\hline 4 & IWT & 0 & 1 & 1 & 1 & 1 & 1 & 1 & 1 \\
\hline 5 & COF & 0 & 0 & 1 & 0 & 1 & 0 & 0 & 0 \\
\hline 6 & ARC & 0 & 1 & 1 & 0 & 1 & 1 & 0 & 0 \\
\hline 7 & RPL & 0 & 1 & 1 & 0 & 1 & 1 & 1 & 0 \\
\hline 8 & PC & 0 & 1 & 1 & 0 & 1 & 1 & 1 & 1 \\
\hline
\end{tabular}

Table 4.2.1.3: Final reachability matrix

\begin{tabular}{|c|c|c|c|c|c|c|c|c|c|c|}
\hline & $\begin{array}{c}\text { Barri } \\
\text { ers }\end{array}$ & 1 & 2 & 3 & 4 & 5 & 6 & 7 & 8 & $\begin{array}{c}\text { D. } \\
\text { P }\end{array}$ \\
\hline & & Y & II & IR & I & C & A & R & BP & \\
G & B & S & W & O & RC & PL & C & \\
\hline 1 & YG & 1 & 1 & 1 & 1 & 1 & 1 & 1 & 1 & 8 \\
\hline 2 & IIB & 0 & 1 & 1 & 0 & 1 & 0 & 0 & 0 & 3 \\
\hline 3 & IRS & 0 & 0 & 1 & 0 & 0 & 0 & 0 & 0 & 1 \\
\hline 4 & IWT & 0 & 1 & 1 & 1 & 1 & 1 & 1 & 1 & 7 \\
\hline 5 & COF & 0 & 0 & 1 & 0 & 1 & 0 & 0 & 0 & 2 \\
\hline 6 & ARC & 0 & 1 & 1 & 0 & 1 & 1 & 0 & 0 & 4 \\
\hline 7 & RPL & 0 & 1 & 1 & 0 & 1 & 1 & 1 & 0 & 5 \\
\hline 8 & PC & 0 & 1 & 1 & 0 & 1 & 1 & 1 & 1 & 6 \\
\hline & De.P & 1 & 6 & 8 & 2 & 7 & 5 & 4 & 3 & \\
\hline
\end{tabular}

\subsubsection{Level Partition :}

From the final reachability matrix, reachability and final antecedent set for each factor are found. The elements for which the reachability and intersection sets are same are the top-level element in the ISM hierarchy. After the identification of top level element, it is separated out from the other elements and the process continues for next level of elements. Reachability set, antecedent set, intersection set along with different level for elements have been shown below in table 4.2.2.1.

Table 4.2.2.1 : Level partition table

\begin{tabular}{|c|c|c|c|c|}
\hline $\begin{array}{c}\text { S. } \\
\text { No. }\end{array}$ & $\begin{array}{c}\text { Reachability } \\
\text { set }\end{array}$ & $\begin{array}{c}\text { Antecedent } \\
\text { set }\end{array}$ & $\begin{array}{c}\text { Intersection } \\
\text { set }\end{array}$ & Iterations \\
\hline 1 & $\mathbf{3}$ & $1,2,3,4,5,6,7,8$ & $\mathbf{3}$ & I \\
\hline 2 & 5 & $1,2,4,5,6,7,8$ & 5 & II \\
\hline 3 & 2 & $1,2,4,6,7,8$ & 2 & III \\
\hline
\end{tabular}

\begin{tabular}{|c|c|c|c|c|}
\hline 4 & 6 & $1,4,6,7,8$ & 6 & IV \\
\hline 5 & 7 & $1,4,7,8$ & 7 & V \\
\hline 6 & 8 & $1,4,8$ & 8 & VI \\
\hline 7 & 4 & 1,4 & 4 & VII \\
\hline 8 & 1 & 1 & 1 & VIII \\
\hline
\end{tabular}

\subsubsection{Driving Power and Dependence Diagram}

The critical success factors described earlier are classified in to four clusters viz. autonomous factor, dependent factors, linkage factors and independent factors are mentioned below.

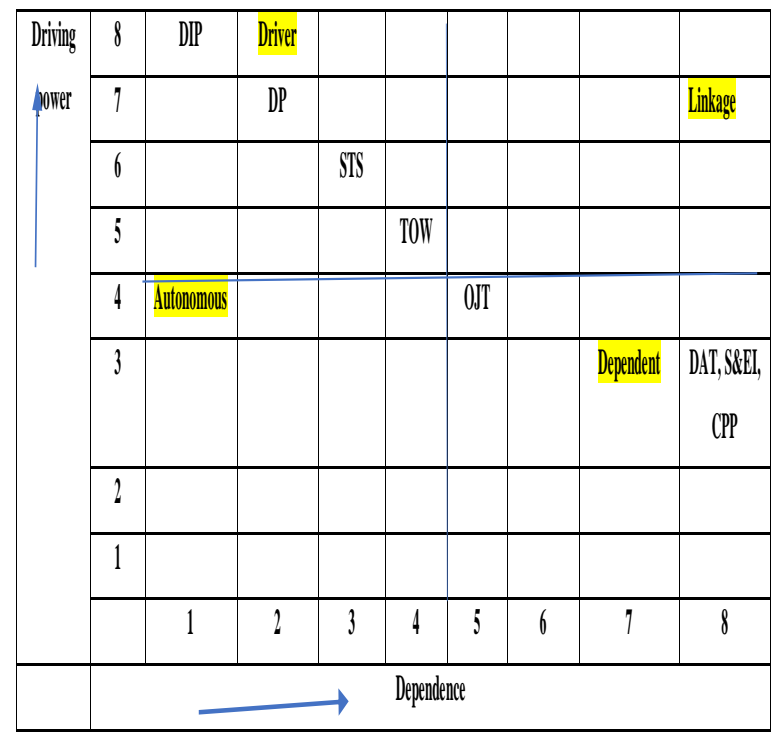

\subsubsection{Iterations}

Table 4.2.5.1: Iteration I

\begin{tabular}{|c|c|c|c|c|}
\hline $\begin{array}{c}\text { S.n } \\
\text { o }\end{array}$ & $\begin{array}{c}\text { Reachability } \\
\text { set }\end{array}$ & $\begin{array}{c}\text { Antecedent } \\
\text { set }\end{array}$ & $\begin{array}{c}\text { Interactio } \\
n \text { set }\end{array}$ & $\begin{array}{c}\text { Iteratio } \\
\mathrm{n}\end{array}$ \\
\hline 1. & $6,7,8$ & $\begin{array}{c}1,2,3,4,5,6,7 \\
8\end{array}$ & $6,7,8$ & I \\
\hline 2. & $3,6,7,8$ & $1,2,3,4,5$ & 3 & \\
\hline 3. & $1,3,6,7,8$ & $1,2,4,5$ & 1 & \\
\hline 4. & $1,2,3,6,7,8$ & $2,4,5$ & 2 & \\
\hline 5. & $\begin{array}{c}1,2,3,4,5,6,7 \\
8\end{array}$ & 4,5 & 4,5 & \\
\hline
\end{tabular}

Table 4.2.5.2: Iteration II

\begin{tabular}{|c|c|c|c|c|}
\hline S.no & $\begin{array}{c}\text { Reachability } \\
\text { set }\end{array}$ & $\begin{array}{c}\text { Antecedent } \\
\text { set }\end{array}$ & $\begin{array}{c}\text { Interaction } \\
\text { set }\end{array}$ & Iteration \\
\hline 2. & $\mathbf{3}$ & $1,2,3,4,5$ & 3 & \multirow{2}{*}{ II } \\
\cline { 1 - 4 } 3. & 1,3 & $1,2,4,5$ & 1 & \multirow{2}{*}{} \\
\cline { 1 - 3 } 4. & $1,2,3$ & $2,4,5$ & 2 & \\
\hline 5. & $1,2,3,4,5$ & 4,5 & 4,5 \\
\hline
\end{tabular}


Table 4.2.5.3: Iteration III

\begin{tabular}{|c|c|c|c|c|}
\hline S.no & $\begin{array}{c}\text { Reachability } \\
\text { set }\end{array}$ & $\begin{array}{c}\text { Antecedent } \\
\text { set }\end{array}$ & $\begin{array}{c}\text { Interaction } \\
\text { set }\end{array}$ & Iteration \\
\hline 3. & $\mathbf{1}$ & $1,2,4,5$ & 1 & \multirow{2}{*}{ III } \\
\cline { 1 - 3 } 4. & 1,2 & $2,4,5$ & 2 & \\
\cline { 1 - 3 } 5. & $1,2,4,5$ & 4,5 & 4,5 & \\
\hline
\end{tabular}

Table 4.2.5.4: Iteration IV

\begin{tabular}{|c|c|c|c|c|}
\hline S.no & $\begin{array}{c}\text { Reachability } \\
\text { set }\end{array}$ & $\begin{array}{c}\text { Antecedent } \\
\text { set }\end{array}$ & $\begin{array}{c}\text { Interaction } \\
\text { set }\end{array}$ & Iteration \\
\hline 4. & $\mathbf{2}$ & $2,4,5$ & 2 & \multirow{2}{*}{ IV } \\
\cline { 1 - 4 } 5. & $2,4,5$ & 4,5 & 4,5 & \\
\hline
\end{tabular}

Table 4.2.5.5: Iteration $\mathrm{V}$

\begin{tabular}{|c|c|c|c|c|}
\hline S.no & $\begin{array}{c}\text { Reachability } \\
\text { set }\end{array}$ & $\begin{array}{c}\text { Antecedent } \\
\text { set }\end{array}$ & $\begin{array}{c}\text { Interaction } \\
\text { set }\end{array}$ & Iteration \\
\hline 5. & $\mathbf{4 , 5}$ & 4,5 & $\mathbf{4 , 5}$ & $\mathrm{V}$ \\
\hline
\end{tabular}

\subsubsection{ISM model}

An ISM model is developed ( as shown in fig. 5 below ) after arranging the elements as per their interaction or dependence relationships.

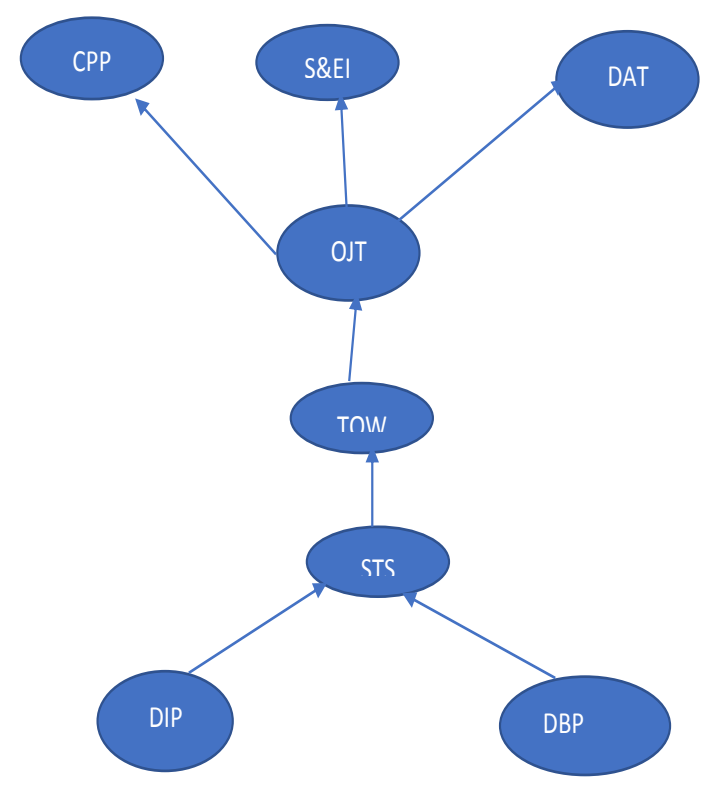

Fig 5 : ISM Model

\section{MANAGERIAL / RESEARCH IMPLICATIONS}

1. A neurodiversity perspective brings together the best elements of both regular and special education to serve the needs of all learners. Neurodiversity inspired educators have a deep respect for student differences and seek ways to join nature and nurture together to create the best ecological niche (or differentiated learning environment) for each student.

2. The neurodiversity movement is not just about inclusion and exercising the responsibility of social justice. It is about maximizing the potential of people as individuals and productivity of companies and society at large by tapping into the total talent pool in a non-traditional fashion.

3. The field could be extended to the concept of child psychology amongst neuro-diverse students .

\section{REFERENCES}

[1] Armstrong, T. 2011. The power of neurodiversity: Unleashing the advantages of your differently wired brain, Cambridge, MA: DeCapo/Perseus.

[2] Armstrong, T. 2012. Neurodiversity in the Classroom: Strength-Based Strategies to Help Students with Special Needs Succeed in School and Life, Alexandria. ASCD Education.

[3] Pollak, D. 2009. Neurodiversity in higher education: Positive responses to specific learning differences, New York, Wiley.

[4] Hendrickx, S. 2010. The adolescent and adult neurodiversity handbook: Asperger' syndrome, ADHD, dyslexia, dyspraxia, and related conditions , London: Jessica Kingsley.

[5] Cosslet, R.L. 2016. Autism in the workplace - an opportunity not a drawback.

[6] Nerenberg, J. 2017. What Neuro-diverse is and why companies should embrace it, The science of work.

[7] Sanchez, D. 2017. Neuro-diverse in the Workforce, Sanchez \& Associates

[8] Middlemiss, N. 2015. Inside SAP's 'Autism at Work' program, shrm.org

[9] Faragher, J. 2018. Why employers should be hiring with Neuro-diverse in mind, People Management

[10] Austin, R. D. \& Pisano, G.P. 2017. Neuro-diverse as a Competitive Advantage, Harvard Business Review.

[11] Oesh, T. 2017. Autism at Work: Hiring and Training Employees on the Spectrum, Training Industry.

[12] Barnett, N. 2018. Individuals with Autism can bring untapped talent to every business, SHRM.org

[13] Powers, M.P. 2018. How to Attract and Support Neurodiverse Talent, SHRM.org

[14] Jacob, A., Scott, M. Falkmer, M. and Falkmer, T. 2015. The Costs and Benefits of Employing an Adult with Autism Spectrum Disorder: A Systematic Review, PLoS ONE 10(10): e0139896. https://doi.org/10.1371/journal.pone.0139896

[15] Warfield, J.N. 1974. Developing interconnection matrices in structural modelling. IEEE Transactions on Systems, Man, and Cybernetics, SMC- 4(1) , 81-87. 